TAPROBANICA, ISSN 1800-427X. October, 2012. Vol. 04, No. 02: 108-111.

(C) Taprobanica Private Limited, 146, Kendalanda, Homagama, Sri Lanka.

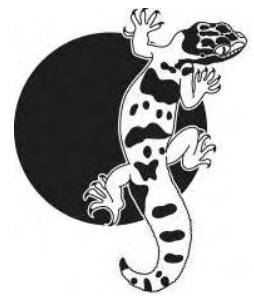

\section{Red Giant Flying Squirrel (Petaurista petaurista) in Assam, India}

Red Giant Flying Squirrel (Petaurista petaurista) is widely distributed throughout Asia in habitat types including moist evergreen broadleaf forest, temperate forest, and scrub forest in both lowlands and montane areas. It is categorized as Least Concern on the IUCN Red List (Walston et al., 2008). Hitherto, no systematic studies have been done on $P$. petaurista in India. We assessed the density of individuals and habitat selection of this species in different habitat types experiencing various degrees of disturbance. We conducted our study in the Jeypore Reserve Forest (JRF; $108 \mathrm{~km}^{2}$ ) of Assam, India $\left(27^{\circ} 06^{\prime}-27^{\circ} 16^{\prime} \mathrm{N}, 95^{\circ} 21^{\prime}-95^{\circ}\right.$ $29^{\prime}$ E; 120-1600 m a.s.l), a rainforest patch of the Eastern Himalayan biodiversity hotspot region (Fig. 1).

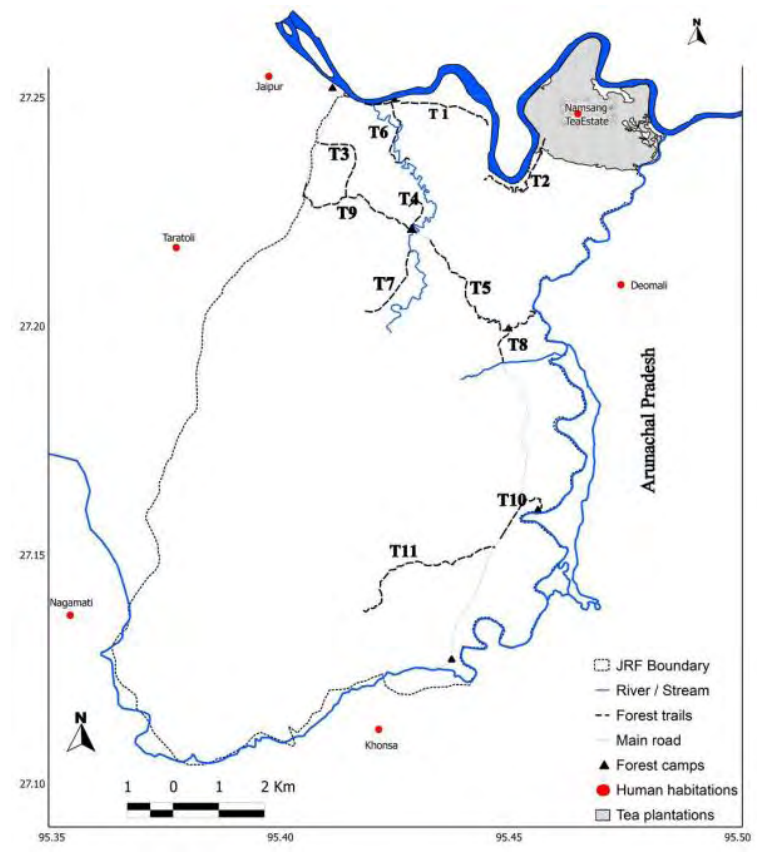

Figure 1: Location of study trails in JRF

We classified regions of our study site as highly disturbed (HD) if frequency of human activities was high (e.g., lopping, traffic on forest roads, livestock grazing) and the canopy was open [mean tree canopy cover <40\%]), moderately disturbed (MD) if low frequencies of human activities were observed with moderate canopy closure (mean tree canopy cover $40-75 \%$ ), or less disturbed (LD) if human activities were not a regular occurrence but people used the forest only during a particular time of the year and the canopy was closed (mean tree canopy cover $>75 \%$ ). Tree canopy cover was measured by placing ten transects of $20 \mathrm{~m}$ x $20 \mathrm{~m}$ randomly in each habitat type. We walked a total of 11 trails in three habitat types $(\mathrm{LD}=4 ; \mathrm{MD}=5$; $\mathrm{HD}=2$ ) covering a total distance of $90 \mathrm{~km}$ from October 2009 to December 2009 (Table 1).

Sightings of $P$. petaurista were recorded on the trails by adopting the "spotlight counts" method (Lee et al., 1993) using Petzel ${ }^{\mathrm{TM}}$ headlamps. We surveyed eleven trails each month between 1800-2400 hrs, when the squirrels are most active (Lin et al., 1988). A total of 33 night walks with 198 hours of effort were conducted. Each survey night a group of observers walked a single trail at a speed of $1 \mathrm{~km} / \mathrm{hr}$ or more. Mostly the LD and MD trails were unsafe to survey at night because of the armed insurgents and high elephant density, reducing survey time. On confirmation of $P$. petaurista, we attempted to identify the number of individuals, perching height on the tree, and GPS location. The index used for estimating relative abundance for nocturnal mammals (Das et al., 2009; Sutherland, 2002) was used for calculating $P$. petaurista encounter rate or 'sightings' per km. We used the SPSS 16.0 software for statistical analysis. We also calculated and plotted differences in encounter rate, group size, and percentage of sightings in relation to the percentage canopy cover among the three forest habitat types.

A total of 78 individuals of $P$. petaurista were recorded over $90 \mathrm{~km}$ of trail (Table 1). The overall average encounter rate was 0.85 individuals $/ \mathrm{km}$ with a mean perching height of $20.21 \pm 1.15 \mathrm{~m}$. Average encounter rate of $P$. petaurista varied among the three habitat types, being highest in LD (1.25 individuals / $\mathrm{km} ; \mathrm{n}=$ 24) followed by MD (1.02 individuals / $\mathrm{km} ; \mathrm{n}=$ $48)$ and $\mathrm{HD}(0.27$ individuals / $\mathrm{km} ; \mathrm{n}=6$; Table 
1). The sighting height (m) on a tree also varied among the three habitats, with a maximum in MD $(24.61 \pm 1.11 \mathrm{~m})$, followed by LD $(16.10 \pm$ $1.79 \mathrm{~m})$, and HD $(14.60 \pm 1.72 \mathrm{~m})$. Mean tree canopy cover in HD habitat was $37.5 \%$, while it was $53 \%$ for $\mathrm{MD}$ and $77.5 \%$ for $\mathrm{LD}$ habitat. Recorded percentage of individuals sighted in relation to the percentage of canopy cover in three habitat types is shown in Figure 2. Field methods for studying squirrels are limited (Weigl \& Osgood, 1974) because of their arboreal nature (Lee et al., 1986; Muul \& Lim, 1978). The recorded encounter rate of $P$. petaurista from our study varied among the different habitat types, being highest in LD, followed by $\mathrm{MD}$ and $\mathrm{HD}$. This is in confirmation with other studies [Barrett (1984),
Lee et al. (1993), Pliosungnoen et al. (2010), Radhakrishna et al. (2006)]. There was, however, no resemblance with the work of Barrett (1984) in Malaysia, where he had reported population densities of Petaurista species to be higher in logged forests than in unlogged forests. We recorded an average encounter rate of 0.85 individuals $/ \mathrm{km}$ which is slightly higher than that of 0.37 individuals $/ \mathrm{km}$ reported (Radhakrishna et al., 2006) in JRF, Assam, India, and 0.36 individuals $/ \mathrm{km}$ reported (Pliosungnoen et al., 2010) in Thailand. A survey from Taiwan (Lee et al., 1993) reported the highest average encounter rate of 1.21 individuals $/ \mathrm{km}$ as compared to our present study (Table 2).

Table 1: Detailed characterization of 11 forest trails walked in JRF (MD = moderately disturbed; LD = less disturbed; $\mathrm{HD}=$ highly disturbed; $\mathrm{BP}=$ bridle path; $\mathrm{FR}=$ forest road; $\mathrm{MR}=$ motorable road).

\begin{tabular}{|c|c|c|c|c|c|c|c|}
\hline $\begin{array}{l}\text { Trail ID } \\
\text { (as in } \\
\text { Fig.1) }\end{array}$ & $\begin{array}{c}\text { Habitat } \\
\text { type }\end{array}$ & $\begin{array}{c}\text { Trail } \\
\text { length } \\
(\mathbf{k m})\end{array}$ & $\begin{array}{l}\text { Total effort } \\
\text { walk (L) }\end{array}$ & $\begin{array}{c}\text { Total } \\
\text { individuals } \\
\text { sighted (n) }\end{array}$ & $\begin{array}{l}\text { Encounter } \\
\text { rate }(n / L)\end{array}$ & $\begin{array}{l}\text { Average } \\
\text { encounter } \\
\text { rate (SD) }\end{array}$ & Remarks \\
\hline $\mathrm{T} 1$ & MD & 4 & 12 & 15 & 1.25 & \multirow{5}{*}{$1.02(0.27)$} & FR \\
\hline T 2 & MD & 3 & 9 & 6 & 0.67 & & FR \\
\hline T 8 & MD & 3 & 9 & 12 & 1.33 & & BP \\
\hline T 9 & MD & 3.5 & 10.5 & 9 & 0.86 & & MR \\
\hline T 10 & MD & 2 & 6 & 6 & 1.00 & & $\mathrm{BP}$ \\
\hline Т 6 & LD & 2 & 6 & 6 & 1.00 & \multirow{4}{*}{$1.25(0.64)$} & $\mathrm{BP}$ \\
\hline T 7 & LD & 2 & 6 & 9 & 1.50 & & BP \\
\hline $\mathrm{T} 4$ & LD & 1 & 3 & 6 & 2.00 & & $\mathrm{BP}$ \\
\hline T 3 & LD & 2 & 6 & 3 & 0.50 & & $\mathrm{BP}$ \\
\hline T 5 & HD & 3.5 & 10.5 & 3 & 0.29 & \multirow[b]{2}{*}{$0.27(0.02)$} & MR \\
\hline $\mathrm{T} 11$ & HD & 4 & 12 & 3 & 0.25 & & $\mathrm{BP}$ \\
\hline Overall & & & 90 & 78 & & $0.85(0.51)$ & \\
\hline
\end{tabular}

Table 2: Comparative accounts of $P$. petaurista encounter rate reported from its distributional range $(*$ Average encounter rate reported from JRF).

\begin{tabular}{llll}
\hline Study site & $\begin{array}{l}\text { Encounter rate estimate } \\
\text { (individual/km) (Habitat } \\
\text { type) }\end{array}$ & $\begin{array}{l}\text { Average encounter } \\
\text { rate from the } \\
\text { study }\end{array}$ & Surveyor \\
\hline $\begin{array}{l}\text { Chitou Experimental } \\
\text { Forest }\end{array}$ & $\begin{array}{l}0.47 \text { (Conifer forest) } \\
1.96 \text { (Hardwood forest) }\end{array}$ & 1.21 & Lee et al., 1993 \\
$\begin{array}{l}\text { Assam and Meghalaya, } \\
\text { India }\end{array}$ & $\begin{array}{l}0.10-0.77 \text { (various forest } \\
\text { types) }\end{array}$ & $0.37 *$ & $\begin{array}{l}\text { Radhakrishna } \text { et al., } \\
\text { Khao Ang Rue Nai }\end{array}$ \\
$\begin{array}{l}\text { Wildlife Sanctuary, } \\
\text { Eastern Thailand }\end{array}$ & 0.36 (Primary forest) & 0.36 & $\begin{array}{l}\text { Pliosungnoen } \text { et al., } \\
2010\end{array}$ \\
\hline
\end{tabular}




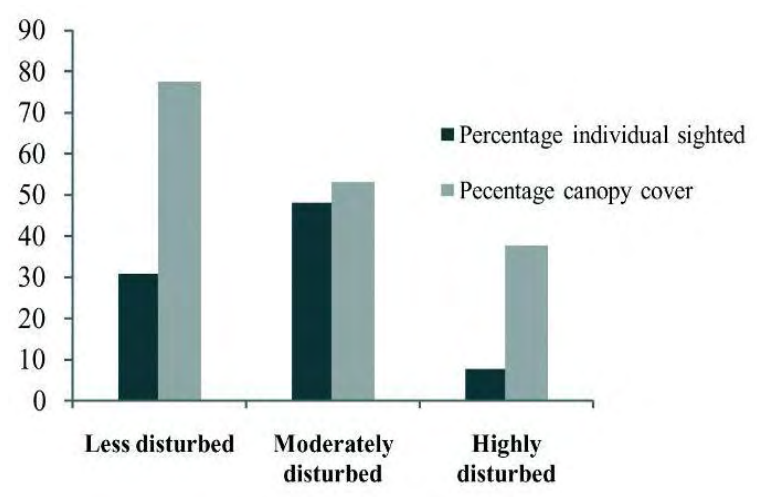

Figure 2: Percentage of individuals of $P$. petaurista sighted in different habitat types having varied percentage of canopy cover.

In general squirrels are very much susceptible to habitat destruction and heavily rely on tall trees for both nesting and feeding (Lee et al., 1986). Thus, forest structure plays an important role in the habitat selection of arboreal mammals (Datta \& Goyal, 1996; Lemos \& Strier, 1992). The high encounter rate in the LD habitat, which is similar to that of Lee et al. (1993) and Pliosungnoen et al. (2010), could be due to the presence of dense forest and homogeneous canopies that allow $P$. petaurista to move and feed with limited exposure to predators. Increased disturbance in HD habitat due to anthropogenic threats, such as logging, NTFP collection, livestock grazing, and encroachment for establishment of tea estates (Kakati, 2004), may have affected $P$. petaurista negatively.

\section{Acknowledgements}

We sincerely thank the Chief Conservator of Forest and Chief Wildlife Warden of Assam for giving us necessary permission to carry out the survey, Divisional Forest Officers of Dibrugarh, Digboi Divisions and Range Officers of Jeypore for logistic supports. R. Munda, S. Barman, S. Kar and R. Sonowal for helping us in the field. Also, V. Krishna (State University of New York, USA) is acknowledged for his technical support. Special thank to Primate Research Centre, Margot Marsh Biodiversity Foundation and U.S. Fish \& Wildlife Service for sponsoring and the financial support. Finally we thank Colin Chapman and Michael Wasserman (McGill University - Canada) for reviewing the manuscript.

\section{Literature Cited}

Barrett, E., 1984. The ecology of some nocturnal, arboreal mammals in the rainforests of peninsular Malaysia. Ph.D. Thesis, University of Cambridge. Cambridge, UK: 187-226.

Das, N., J. Biswas, J. Das, P. C. Ray, A. Sangma and P. C. Bhattacharjee, 2009. Status of Bengal slow loris Nycticebus bengalensis (Primates: Lorisidae) in Gibbon Wildlife Sanctuary, Assam, India. Journal of Threatened Taxa, 1 (11): 558561.

Datta, A. and S. P. Goyal, 1996. Comparison of forest structure and use by the Indian giant squirrel (Ratufa indica) in two riverine forests of Central India. Biotropica, 28: 394-399.

Kakati, K., 2004. Impact of forest fragmentation on the hoolock gibbon in Assam, India. Ph.D. thesis, University of Cambridge, Cambridge, United Kingdom: 12-66.

Lee, P. F., D. R. Progulske and Y. S. Lin, 1986. Ecological studies on the two sympatric giant flying squirrels (Petaurista petaurista and $P$. alborufus) in Taiwan. Bulletin of the Institute of Zoology, Academia sinica, 25 (1): 113-124.

Lee, P. F., D. R. Progulske and Y. S. Lin, 1993. Spotlight counts of gaint flying squirrels (Petaurista petaurista and P.alborufus) in Taiwan. Bulletin of the Institute of Zoology, Academia Sinica, 32 (1): 54-61.

Lemos De Sa, R. M. and K. B. Strier, 1992. A preliminary comparison of forest structure and use by two isolated groups of woolly spider monkeys, Brachyteles archanoides. Biotropica, 24: 455-459.

Lin, Y. S., L. Y. Wang and L. L. Lee, 1988.The behaviour and activity pattern of giant flying squirrels (Petaurista p. grandis). Quarterly Journal Chinese Forestry, 21 (3):81-94 (in Chinese, English abstract).

Meijaard, E., D. Sheil, R. Nasi, D. Augeri, B. Rosenbaum, D. Iskandar, T. Setyawati, M. Lammertink, I. Rachmatika, A. Wong, T. Soehartono, S. Stanley and T. O'Brien, 2005. Life after logging: reconciling wildlife conservation and production forestry in Indonesian Borneo. Centre for International Forestry Research, Bogor, Indonesia: 30-34.

Muul, I. and L. B. Lim, 1978. Comparative morphology, food habits, and ecology of some Malaysian arboreal rodents. In: The ecology of 
arboreal folivores, G. G. Montgomery, (ed.). Smithsonian Institute, Washington D.C. 361-368.

Nandini, R. and N. Parthasarathy, 2008. Food habits of the Indian giant flying squirrel (Petaurista philippensis) in a rain forest fragment, Western Ghats. Journal of Mammalogy, 89 (6): 1550-1556.

Pliosungnoen, M., G. Gale and T. Savini, 2010. Density and microhabitat use of Bengal slow loris in primary forest and non-native plantation forest. American Journal of Primatology, 72: 11081117.

Radhakrishna, S., A. B. Goswami and A. Sinha, 2006. Distribution and conservation of Nycticebus bengalensis in Northeastern India. International Journal of Primatology, 27:971-982.

Robert, D. and P. DeVries, 1999. Tropical Rain Forest Structure and the Geographical Distribution of Gliding Vertebrates. Biotropica, 22 (4): 432- 434.

Sutherland, W. J., 2002. Mammals. In: Ecological censusing technique, Sutherland, W. J. (ed.). Cambridge University Press: 260-278

Walston, J., J. W. Duckworth, S. U. Sarker and S. Molur, 2008. Petaurista petaurista. In: IUCN 2011. IUCN Red List of Threatened Species. Version 2011.2. <www.iucnredlist.org>. Downloaded on 10 April 2012.

Weigl, P. D. and D. W. Osgood, 1974. Study of the northern flying squirrel, Glaucomys sabrinus, by temperature telemetry. The American Midland Naturalist Journal, 92: 482-486.

Submitted: 14 May 2012, Accepted: 26 July 2012 Sectional Editor: Vincent Nijman

P. C. Ray ${ }^{1,5}$, A. Kumar ${ }^{1}$, J. Biswas ${ }^{2}$, N. Das ${ }^{2,3,4}$, A. Sangma ${ }^{3}$, K. Sarma ${ }^{1}$ and M. Krishna ${ }^{1}$

${ }^{1}$ North Eastern Regional Institute of Science \& Technology, Arunachal Pradesh, India. ${ }^{5}$ Email: parimalcray@gmail.com

${ }^{2}$ Primate Research Centre Northeast, Assam, India.

${ }^{3}$ Department of Zoology, Gauhati University, Assam, India.

${ }^{4}$ Department of Anthropology, Oxford Brookes University, United Kingdom. 